\title{
Be on the Lookout for Bacterial Leaf Streak of Corn'
}

\author{
K. A. Korus and N. S. Dufault ${ }^{2}$
}

\section{Symptoms and Survival}

Bacterial leaf streak (BLS) is a new corn disease that has been found in several major corn-producing regions of the United States (Korus et al. 2017). Currently, the impact this disease has on corn yields is unclear, but severe infections can significantly decrease the leaf area available for photosynthesis (Figure 1). This disease has moved rapidly across large geographical areas like the Midwest. In 2014, BLS was observed in a few Nebraska counties, and, by 2016, had been reported in nine states (Figure 2). Florida growers should be on the lookout for BLS, as it is spreading quickly across the US. Early detection is critical to mitigate the potential damage from this disease and to keep Florida's corn production safe. The BLS pathogen cannot survive for extended periods in the soil but does persist in untilled, infected crop residue. From the infected crop residue, the bacteria can be splashed by rain or irrigation upwards onto the lower leaves of corn and upward through the corn canopy. To date, insufficient data is present to understand the movement of this bacterial pathogen within the corn plant. However, it appears that the infections are confined to the leaves and the pathogen does not become systemic. It is not clear at this point if seed transmission is possible. Data from epidemics that occurred during the 2015 and 2016 growing seasons in Nebraska indicates that infections occur under cool $\left(\sim 55^{\circ} \mathrm{F}-75^{\circ} \mathrm{F}\right)$ nighttime temperatures. However, disease was observed to occur throughout the growing season. There is still a lot to learn about the growth and development of this pathogen in corn.

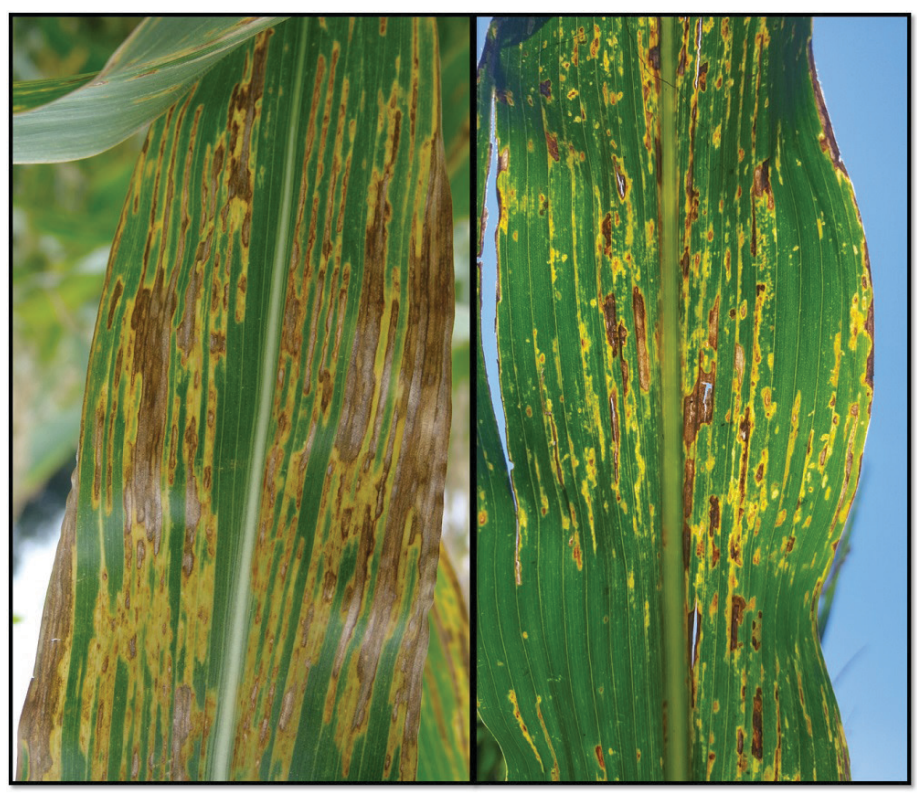

Figure 1. Corn leaves with severe BLS infection. Lesions are confined to the leaf veins. Left image: Note the wavy margins of the long yellow/ brown lesions. Right image: Lesions become translucent when lit from behind.

Credits: Dr. Tamra Jackson-Zeims, University of Nebraska-Lincoln

\section{Identification}

Disease identification is a critical first step when developing management strategies for any pathogen. Therefore, it is important to distinguish this disease from fungal diseases in order to minimize the risk of applying costly fungicides that will not control BLS. BLS is caused by the bacterium Xanthomonas vasicola pv. vasculorum. It causes long, interveinal leaf streak symptoms that are tan to brown in

1. This document is PP341, one of a series of the Plant Pathology Department, UF/IFAS Extension. Original publication date November 2018. Visit the EDIS website at https://edis.ifas.ufl.edu for the currently supported version of this publication.

2. K. A. Korus, Extension agent II, Alachua County; and N. S. Dufault, assistant professor, Plant Pathology Department; UF/IFAS Extension, Gainesville, FL 32611. 
color, but appear yellow when lit from behind (Figure 1). The lesions are confined to the leaf veins and the edges of lesions are wavy. Individual lesions will not cross the veins; however, multiple lesions may coalesce and appear to cross the vein tissue.

There are some common corn diseases that resemble bacterial leaf streak (Table 1). Similarities occur mostly during early development of foliar lesions (Figure 3). It is important to remember that field diagnostics are difficult and that samples resembling BLS should be submitted for further testing. See the EDIS publication PP249 (http:// edis.ifas.ufl.edu/pdffiles/MG/MG44200.pdf) for further information about disease diagnosis.

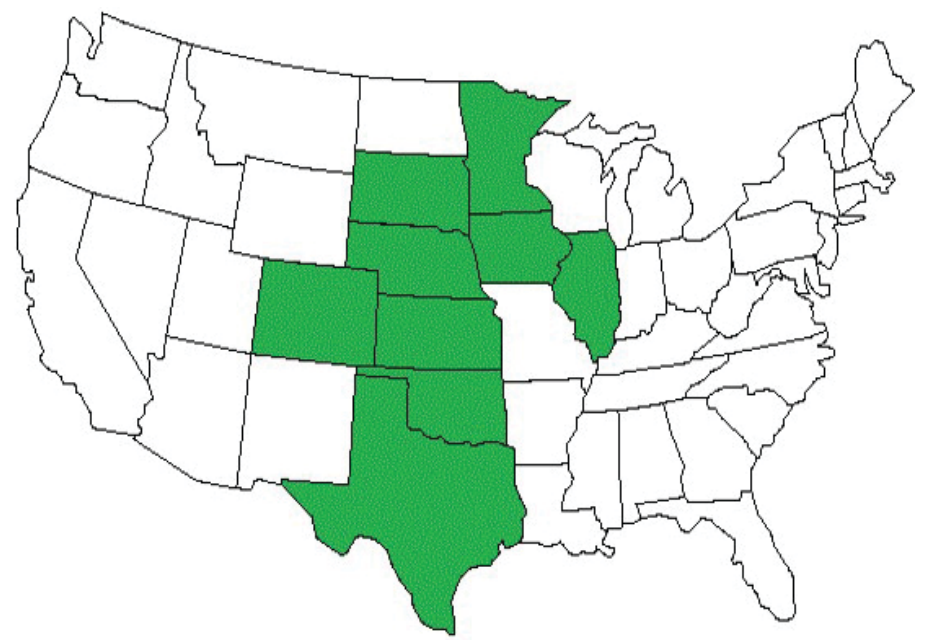

Figure 2. 2016 distribution of BLS in the United States. States with a positive identification of the disease are colored green.

Credits: Nebraska Department of Agriculture

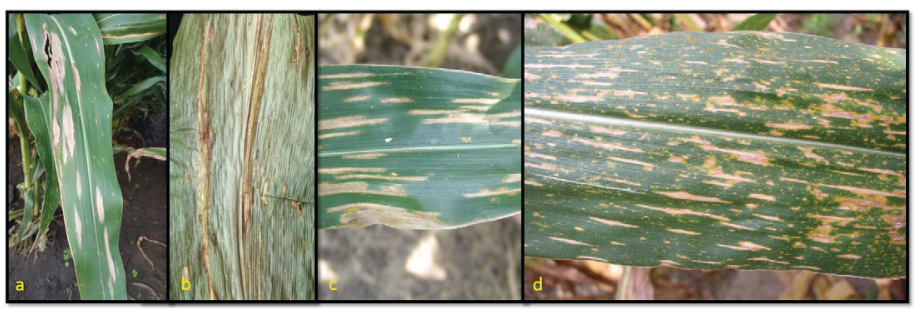

Figure 3. Typical field symptoms: a) Northern corn leaf blight (lesions in early stages of development resemble those produced by BLS). As disease progresses, the lesions become larger, move across the leaf veins and take on a 'cigar shaped' appearance; b) Bacterial leaf stripe (long lesions with wavy margins not confined by leaf veins); c) Gray leaf spot (vein-limited, rectangular lesions with straight edges); d) Southern corn leaf blight (elongated tan lesions that are often rounded with age, limited by veins).

Credits: a) Dr. Tamra Jackson-Ziems, University of Nebraska-Lincoln; b) Dr. Suzanne Bissonnette, University of Illinois; c) Dr. Tamra JacksonZiems, University of Nebraska-Lincoln; and d) Dupont Pioneer

\section{Distribution}

BLS was first observed on corn in Nebraska in 2013 and has since spread throughout the Midwest. Nine states have confirmed the disease: Colorado, Illinois, Iowa, Kansas, Minnesota, Oklahoma, South Dakota, and Texas (pers. communication, Julie Van Meter State Plant Regulatory Officer, Nebraska Dept. of Agriculture) (Figure 2). Further survey information is needed to better understand the distribution of this pathogen in the US and if it can infect multiple plant species (Schlund et al. 2017).

Xanthomonas vasicola pv. vasculorum is historically known for causing gumming disease of sugarcane (Cook 1928). The geographic distribution of sugarcane gumming disease can be seen in Figure 4. In Africa, the disease can be found in Ghana, Madagascar, Malawi, Mauritius, Mozambique, Rèunion, South Africa, Swaziland, and Zimbabwe. In Central America and the Caribbean, the disease is reported in Antigua and Barbuda, Belize, Cuba, Dominica, the Dominican Republic, Guadeloupe, Jamaica, Martinique, Panama, Puerto Rico, Saint Kitts and Nevis, and Trinidad and Tobago. In North America, gumming disease of sugarcane has only been observed in Mexico. In South America, the disease has been reported in Argentina, Colombia, and French Guiana. This disease has also been reported in Papua New Guinea.

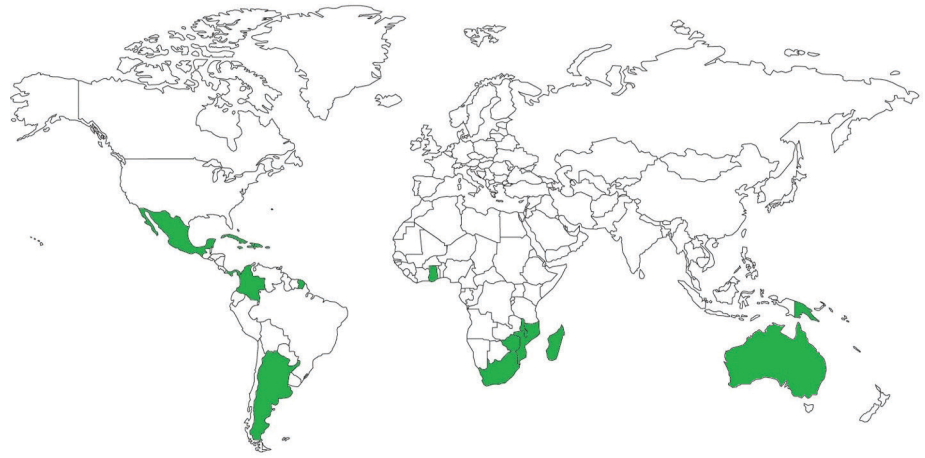

Figure 4. World distribution of gumming disease of sugarcane caused by $X$. vasicola pv. vasculorum. Note: Some of the countries listed are not on the map as they are too small to appear.

Credits: M. T. Cook, the 1928 Ref. Book Sugar Ind. Of the World

\section{Management}

Currently, there are no effective bactericides recommended for control of bacterial leaf streak. Pathogen spread and disease incidence can be reduced by tillage of crop residue into the soil at the end of the growing season and/or by planting non-host crops. Peanuts, soybeans, cotton, watermelons, potatoes, and peppers would be examples of non-grass crops that could be rotated for managing this disease. A list of potential grass crop hosts and non-hosts has also been prepared and can be found in the University 
of Nebraska’s Crop Watch article 'Bacterial Leaf Streak of Corn' (http://cropwatch.unl.edu/2017/bacterial-leaf-streakcorn). Although there are no commercially available field corn or sweet corn varieties labeled as resistant to this pathogen, representatives from the Nebraska seed corn industry have noticed levels of resistance within inbred field corn lines. It is reasonable to assume that resistant hybrids could be available in the future. However, resistance to BLS has not been identified in sweet corn cultivars.

\section{Conclusions}

Although X. vasicola pv. vasculorum has not been identified in Florida, the threat to Florida agriculture is exacerbated by the presence of both corn and sugarcane in the state. It is important to be diligent in keeping a lookout for bacterial leaf streak of corn or gumming disease of sugarcane. Diagnosis from field symptoms alone can be difficult, as there are multiple other diseases that have similar symptom expression. When in doubt or for confirmation of diagnosis, consider submitting a sample to the University of Florida's Plant Diagnostic Center, 2570 Hull Rd. Bldg. 1291. Gainesville, FL 32611-0830 (phone: (352) 392-1795; email: pdc@ifas.ufl.edu).

Table 1. Four foliar leaf blight diseases of corn that can mimic bacterial leaf streak during early stages of disease development.

\begin{tabular}{|l|l|l|}
\hline \multicolumn{1}{|c|}{ Disease } & \multicolumn{1}{c|}{ Pathogen (Type) } \\
\hline Northern Corn Leaf Blight & Exserohilum turcicum (Fungus) & $\begin{array}{l}\text { Key Symptoms } \\
\text { Large 'cigar shaped'lesions that cross the veins (Figure } \\
\text { Sa) }\end{array}$ \\
\hline Southern Corn Leaf Blight & Bipolaris maydis (Fungus) & $\begin{array}{l}\text { Elongated tan lesions that are often round, limited by } \\
\text { veins (Figure 3d) }\end{array}$ \\
\hline Gray Leaf Spot & Cercospora zea-maydis (Fungus) & Vein-limited, rectangular lesions with straight edges. \\
\hline Bacterial Leaf Stripe & Burkholderia andropogonis (Bacteria) & Long lesions that are not vein-limited (Figure 3b). \\
\hline
\end{tabular}

